\title{
Deoxyribonucleic Acid Base Composition of Cyanobacteria
}

\author{
By MICHAEL HERDMAN,* MONIQUE JANVIER, \\ JOHN B. WATERBURY, $\dagger$ ROSMARIE RIPPKA AND \\ ROGER Y. STANIER \\ Unité de Physiologie Microbienne, Département de Biochimie et Génétique Microbienne, \\ Institut Pasteur, 28 rue du Docteur Roux, Paris 75015, France \\ AND MANLEY MANDEL \\ Department of Biology, The University of Texas, \\ M. D. Anderson Hospital and Tumor Institute at Houston, Texas 77030, U.S.A.
}

(Received 8 June 1978)

The DNA base compositions of 176 strains of cyanobacteria were determined by thermal denaturation or by $\mathrm{CsCl}$ density gradient centrifugation. A summary of all data now available for this prokaryotic group is presented and the taxonomic and evolutionary implications are discussed.

\section{INTRODUCTION}

Edelman et al. (1967) reported mean DNA base compositions for a limited number of strains of cyanobacteria, representative of many different sub-groups. More extensive data were published by Stanier et al. (1971) for one sub-group, the unicellular cyanobacteria. In this paper we present data for a large number of additional strains, broadly representative of this major prokaryotic taxon.

\section{METHODS}

Strains. The strains examined are all maintained in the Pasteur Culture Collection (PCC) and havenow been deposited in the American Type Culture Collection (ATCC). They are identified here by both PCC and ATCC strain numbers. Full strain histories, media employed for cultivation and the explanation of generic terminology are given by Rippka et al. (1979). An additional strain (Oscillatoria agardhii) was isolated by Dr F. I. Kappers from the Veluwemeer, The Netherlands, and is now in pure culture as strain PCC 7805.

Extraction of DNA. DNA for use in thermal denaturation experiments was purified by a method modified from that of Britten et al. (1968). Harvested cells (approximately $5 \mathrm{~g}$ wet wt) were suspended in $20 \mathrm{ml}$ lysis mixture containing $8 \mathrm{M}$-urea, $1 \mathrm{M}$ - $\mathrm{NaClO}_{4}, 0.01 \mathrm{~m}$-EDTA (disodium salt) and $1 \%(\mathrm{w} / \mathrm{v}$ ) sodium dodecyl sulphate (SDS) in $0.24 \mathrm{M}$-phosphate buffer ( $\mathrm{pH} \mathrm{7.0)}$ ), disrupted by passage through a French press at $76 \mathrm{MPa}$, and partially deproteinized by shaking with an equal volume of chloroform/3-methylbutan-1-ol $(24: 1, \mathrm{v} / \mathrm{v})$ at room temperature for $30 \mathrm{~min}$. Following centrifugation at $3000 \mathrm{~g}$ for $15 \mathrm{~min}$ the upper (aqueous) phase, containing DNA, was retained. DNA-grade hydroxyapatite (HAP; $2 \mathrm{~g}$; Bio-Rad) was suspended in $20 \mathrm{ml}$ $0.24 \mathrm{M}$-phosphate buffer (pH 7.0), boiled for $30 \mathrm{~min}$, centrifuged at low speed, and washed twice with $15 \mathrm{ml}$

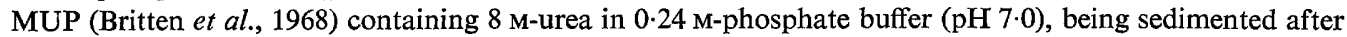
each wash by brief low-speed centrifugation. The deproteinized nucleic acid solution was mixed with the washed HAP and stirred ( $5 \mathrm{~min}$ ) to permit binding of DNA. The bound DNA was purified by washing the mixture (by centrifugation) seven times with $15 \mathrm{ml}$ MUP, to remove RNA and residual protein, and then four times with $15 \mathrm{ml} \mathrm{0.014} \mathrm{M-phosphate} \mathrm{buffer}(\mathrm{pH} \mathrm{7 \cdot 0)}$, to remove urea. The purified DNA was eluted

* Present address: Department of Biological Sciences, The University, Dundee DD1 4HN.

$\uparrow$ Present address: Biology Department, Woods Hole Oceanographic Institution, Woods Hole, Massachusetts 02543 , U.S.A. 
from the HAP in two washes $(7 \mathrm{ml})$ of $0.4 \mathrm{M}$-phosphate buffer $(\mathrm{pH} 7 \cdot 0)$, transferred to cleaned dialysis sacs and concentrated to at least $250 \mu \mathrm{g} \mathrm{ml}^{-1}$ in Aquacide III (polyethyleneglycol, B grade, Calbiochem). The preparation was finally dialysed exhaustively against several changes of $0 \cdot 1 \times$ SSC buffer (SSC buffer, pH $7 \cdot 0$, is $0.15 \mathrm{M}-\mathrm{NaCl} / 0.015 \mathrm{M}$-trisodium citrate), centrifuged to remove any remaining traces of HAP, and stored at $4{ }^{\circ} \mathrm{C}$ over chloroform.

This method permitted the rapid, simultaneous purification of up to eight DNA samples in a $8 \times 50 \mathrm{ml}$ rotor. DNA solutions were routinely checked spectrophotometrically, by a modification (Taggart, 1967) of the orcinol reaction (Schneider, 1957) and by measurement of hyperchromicity following thermal denaturation, in order to confirm their purity.

DNA for $\mathrm{CsCl}$ ultracentrifugation studies was extracted after disruption in the Hughes Press at $-18{ }^{\circ} \mathrm{C}$. The paste was thawed in saline/EDTA containing $2 \%$ SDS and deproteinized by shaking with an equal volume of freshly redistilled neutralized phenol saturated with the saline/EDTA buffer and a 24:1 (v/v) mixture of chloroform and 3-methylbutan-1-ol. Following centrifugation at $8000 \mathrm{~g}$ for $10 \mathrm{~min}$ the aqueous phase was removed and impure nucleic acids were precipitated with 2 vol. $95 \%(\mathrm{v} / \mathrm{v})$ ethanol. The spooled fibres were washed twice in $70 \%$ ethanol, air-dried and dissolved in a small volume of SSC buffer.

Estimation of DNA base composition. Thermal denaturation of DNA in $0.1 \times \mathrm{SSC}$ buffer was performed in sealed cuvettes, in triplicate, in a Gilford 240 spectrophotometer fitted with automatic cuvette programmer, thermosensor, and analogue multiplexer. The fourth cuvette contained a solution of guanine to enable correction to be made for solvent expansion. The temperature increment was $0 \cdot 1{ }^{\circ} \mathrm{C} \mathrm{min}-1$. The thermosensor and temperature recording equipment were calibrated with DNA samples of known base composition. The DNA base composition was calculated from the temperature midpoint of thermal denaturation $\left(T_{m}\right)$ using the equation of Marmur \& Doty (1962), and expressed as percentage guanine plus cytosine to total base content ( $\mathrm{mol} \% \mathrm{GC})$. Buoyant densities in neutral $\mathrm{CsCl}$ were measured as previously described (Stanier et al., 1971) using the same reference DNA samples as in that study.

\section{RESULTS}

The data on DNA base composition in Tables 1 to 5 include all values now available for cyanobacteria, derived both from the present study and from preceding publications (Edelman et al., 1967; Craig et al., 1969; Kaye et al., 1967; Stanier et al., 1971; Rippka et al., 1974). A careful comparison of cyanobacterial strain histories (Rippka et al., 1979) has shown that a few of the strains, previously assumed to be of independent origin, are probably identical isolates; in such cases, a value for only one strain is included in the tabulations.

The assignment of strains to sections and genera follows the taxonomic proposals of Rippka et al. (1979). The failure to assign specific names to most strains is deliberate; the reasons for this policy are discussed by Rippka et al. (1979). Within each genus, the strains are listed in order of the increasing GC content of their DNA. Strains of independent origin which appear to be closely related in terms of their phenotypic properties (Rippka et al., 1979) are enclosed within braces in the Tables.

Section I includes all unicellular cyanobacteria that reproduce either by binary fission (most genera) or by budding (genus Chamaesiphon). The two largest assemblages of strains in this section are representatives of the genera Synechococcus and Synechocystis, defined, respectively, as rod-shaped and spherical unicellular organisms, not enclosed by sheaths, and multiplying by binary fission. Both genera are characterized by wide DNA base compositional spans and by clear-cut internal discontinuities in base composition (Table 1), as had been recognized previously by Stanier et al. (1971). The analysis of additional strains has revealed the existence of one further discrete base compositional cluster in the genus Synechococcus. The members of this genus fall into three distinct groups with mean DNA base compositions in the ranges 39 to 43,47 to 56 and 66 to $71 \mathrm{~mol} \%$ GC. Phenotypic analyses suggest that each base compositional cluster includes representatives of two or more species (Stanier et al., 1971; unpublished observations). Two strains in the low base compositional cluster, PCC 7418 and 7424, are readily distinguishable by their large cells, which resemble in size and shape those of the ensheathed cyanobacteria of the genus Gloeothece. All other strains of Synechococcus have much smaller cells and differ little from 
Table 1. Mean DNA base compositions of strains assigned to Section I

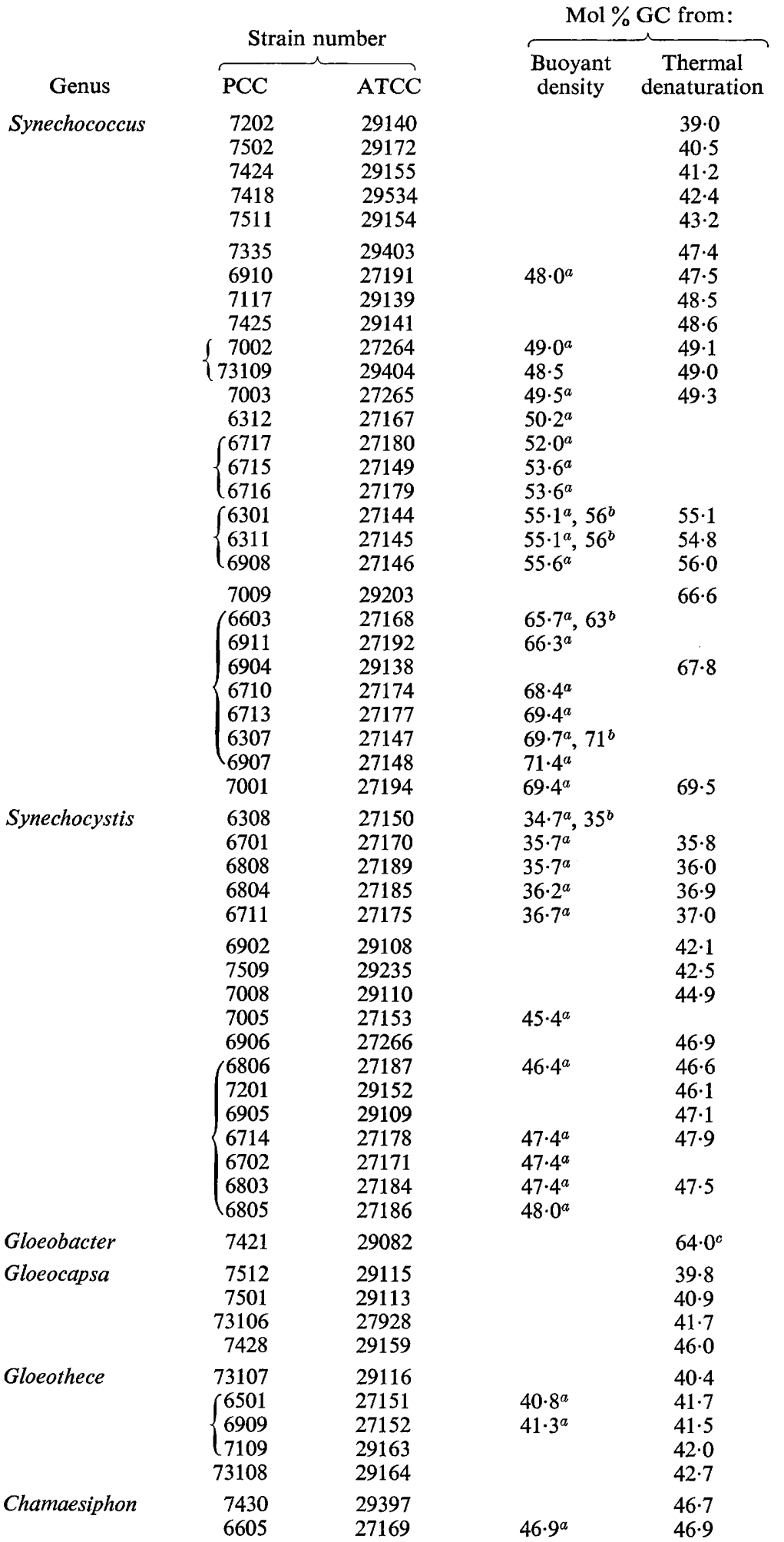

${ }^{a}$ From Stanier et al. (1971); ${ }^{b}$ from Edelman et al. (1967); ${ }^{c}$ from Rippka et al. (1974). 
Table 2. Mean DNA base compositions of strains assigned to Section II

\begin{tabular}{|c|c|c|c|c|}
\hline \multirow{3}{*}{ Genus } & \multirow{2}{*}{\multicolumn{2}{|c|}{ Strain number }} & \multicolumn{2}{|c|}{ Mol \% GC from: } \\
\hline & & & \multirow{2}{*}{$\begin{array}{c}\text { Buoyant } \\
\text { density }\end{array}$} & \multirow{2}{*}{$\begin{array}{c}\text { Thermal } \\
\text { denaturation }\end{array}$} \\
\hline & PCC & ATCC & & \\
\hline Dermocarpa & $\begin{array}{l}7438 \\
7437 \\
7302 \\
7303 \\
7301 \\
7304\end{array}$ & $\begin{array}{l}29372 \\
29371 \\
29368 \\
29369 \\
29367 \\
29370\end{array}$ & $44^{a}$ & $\begin{array}{l}38 \cdot 3 \\
40 \cdot 7 \\
42 \cdot 9 \\
43 \cdot 6 \\
44 \cdot 0 \\
44 \cdot 0\end{array}$ \\
\hline Xenococcus & $\begin{array}{l}7307 \\
7305\end{array}$ & $\begin{array}{l}29375 \\
29373\end{array}$ & & $\begin{array}{l}43 \cdot 6 \\
44 \cdot 2\end{array}$ \\
\hline Dermocarpella & 7326 & 29376 & & $45 \cdot 1$ \\
\hline Myxosarcina & $\begin{array}{l}7325 \\
7312\end{array}$ & $\begin{array}{l}29378 \\
29377\end{array}$ & & $\begin{array}{l}42 \cdot 7 \\
44 \cdot 0\end{array}$ \\
\hline Chroococcidiopsis & 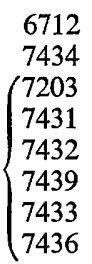 & $\begin{array}{l}27176 \\
29382 \\
27900 \\
29379 \\
29380 \\
29384 \\
29381 \\
29383\end{array}$ & $40 \cdot 8^{b}$ & $\begin{array}{l}40 \cdot 2 \\
45 \cdot 8 \\
45 \cdot 8 \\
45 \cdot 9 \\
46 \cdot 0 \\
46 \cdot 3 \\
46 \cdot 4 \\
46 \cdot 4\end{array}$ \\
\hline Pleurocapsa group & $\begin{array}{l}7440 \\
7516 \\
7310 \\
7320 \\
7322 \\
7321 \\
7319 \\
7314 \\
7324 \\
7317 \\
7327\end{array}$ & $\begin{array}{l}29394 \\
29396 \\
29385 \\
29389 \\
29391 \\
29390 \\
29388 \\
29386 \\
29392 \\
29387 \\
29393\end{array}$ & & $\begin{array}{l}39 \cdot 3 \\
41 \cdot 0 \\
42 \cdot 8 \\
43 \cdot 0 \\
43 \cdot 0 \\
43 \cdot 0 \\
43 \cdot 2 \\
43 \cdot 3 \\
43 \cdot 3 \\
45 \cdot 4 \\
46 \cdot 5\end{array}$ \\
\hline
\end{tabular}

one another in gross structural respects. Thus members of different base compositional clusters may be virtually indistinguishable by microscopic examination.

Base compositional data on six newly isolated Synechocystis strains have not significantly extended the overall range for this genus (Stanier et al., 1971). Synechocystis contains two distinct strain clusters with mean DNA base compositions in the ranges of 35 to 37 and 42 to $48 \mathrm{~mol} \%$ GC. In the latter (high GC) group, seven independent isolates appear, in terms of their phenotypic properties, to be members of a single species; they are also closely similar in base composition.

The four other genera assigned to Section I are each represented by a small number of strains. The spans of DNA base composition within these genera may therefore be wider than they now appear (Table 1). The four strains assigned to the genus Gloeocapsa differ structurally but have a relatively narrow base compositional span of 40 to $46 \mathrm{~mol} \% \mathrm{GC}$. The five members of the genus Gloeothece, which may represent at least two different species, are closely similar in DNA base composition (40 to $43 \mathrm{~mol} \% \mathrm{GC}$ ). Chamaesiphon is represented by two strains, of identical base composition ( $47 \mathrm{~mol} \% \mathrm{GC}$ ), which are readily distinguishable by their phenotypic properties (Waterbury \& Stanier, 1977). Gloeobacter is represented by a single strain of mean DNA base composition $64 \mathrm{~mol} \%$ GC.

The cyanobacteria of Section II, the pleurocapsalean group, are distinguished by a special mode of reproduction: the release of small, spherical daughter cells (baeocytes) which arise 
Table 3. Mean DNA base compositions of strains assigned to Section III

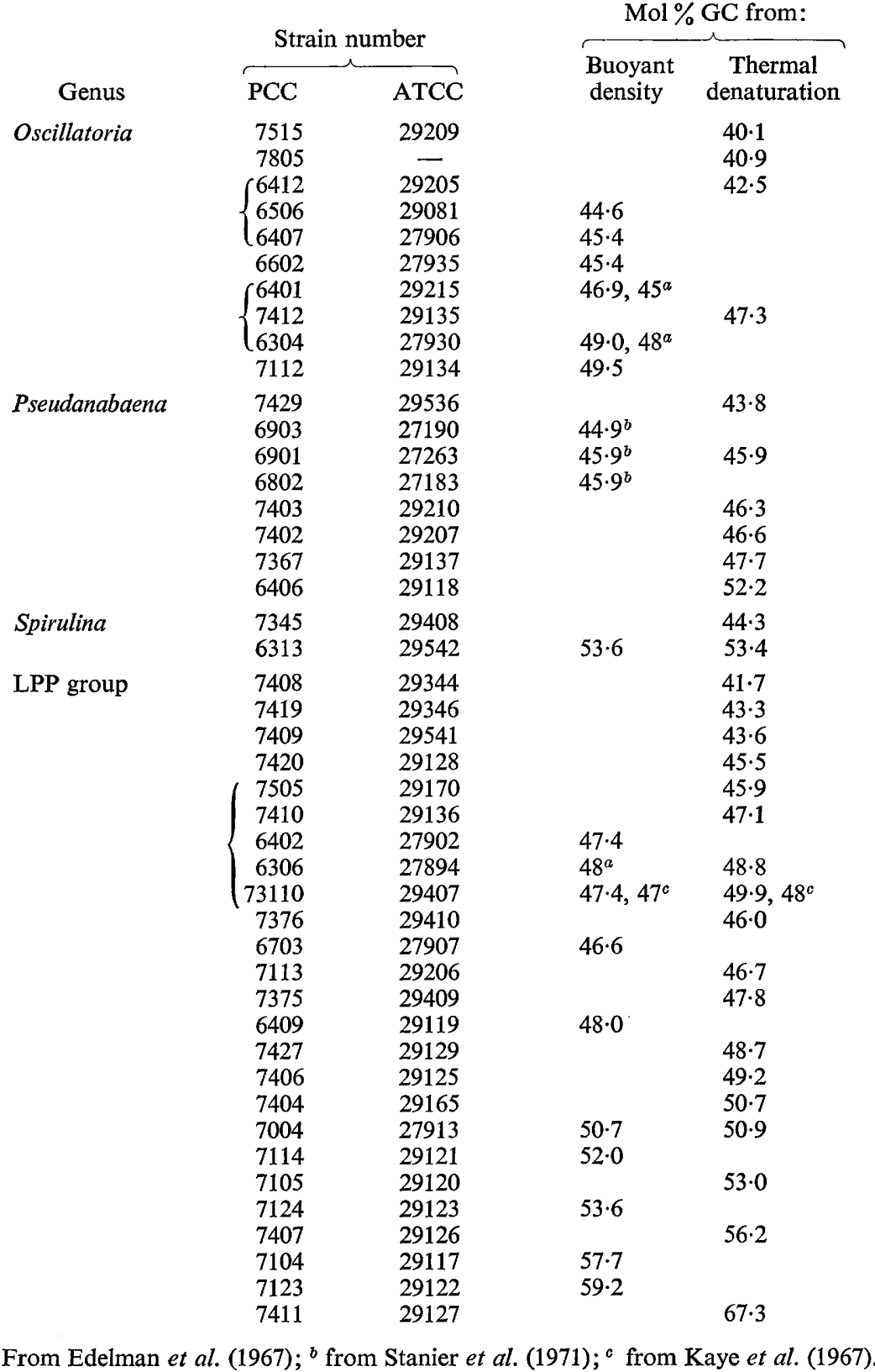

by multiple fission within the outer wall layer of a much larger vegetative cell. The genera included are diverse in developmental respects (Waterbury \& Stanier, 1978) and are, in fact, assigned to two separate orders, the Dermocarpales and the Pleurocapsales, in the traditional phycological classification of the cyanobacteria (e.g. Bourrelly, 1970). However, the section is remarkably uniform in DNA base composition (Table 2), the total span for the 30 strains examined being 38 to $47 \mathrm{~mol} \%$ GC. Within the genus Chroococcidiopsis, six of the eight strains appear to be members of one species in terms of their phenotypic pro- 
Table 4. Mean DNA base compositions of strains assigned to Section IV

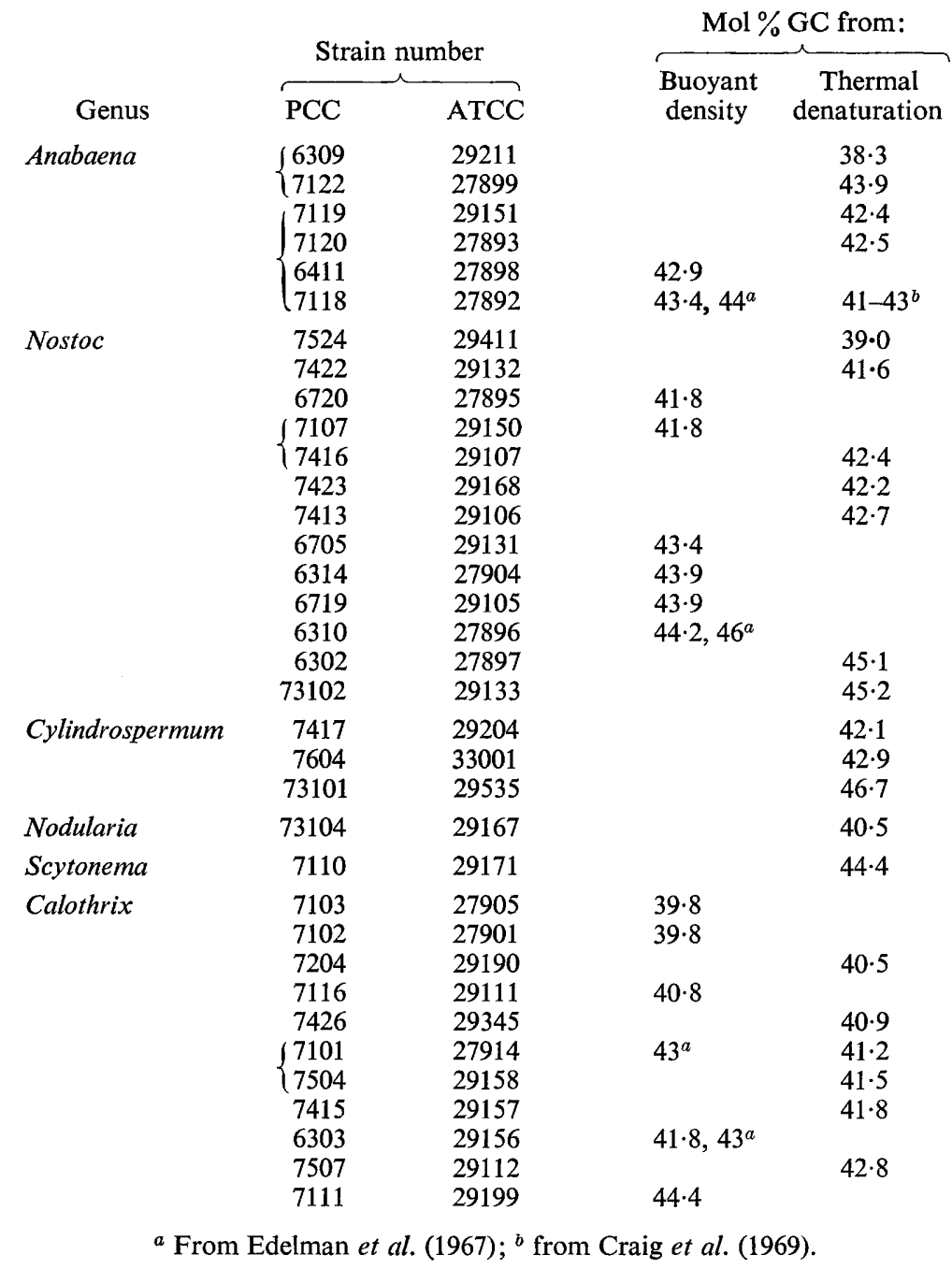

perties; they are also closely similar in DNA base composition, and significantly different in this respect from the one other strain of this genus so far examined.

The generic sub-division of the filamentous, non-heterocystous cyanobacteria assigned to Section III still presents many unsolved problems, as discussed by Rippka et al. (1979). Three genera-Oscillatoria, Pseudanabaena and Spirulina - can be recognized and distinguished on structural grounds. However, a clear-cut generic assignment for many of the strains cannot yet be made and, since these strains share, in various combinations, the properties which have been ascribed to the genera Lyngbya, Plectonema and Phormidium, they have been placed in a provisional category, termed the LPP group.

Oscillatoria and Pseudanabaena, represented by 10 and 8 strains respectively, have relatively narrow and similar base compositional spans of 40 to 50 and 44 to $52 \mathrm{~mol} \% \mathrm{GC}$ (Table 3). The two strains of Spirulina analysed contained DNA with 44 and $54 \mathrm{~mol} \%$ GC. These two strains differ greatly in phenotypic respects: strain PCC 7345 contains gas vacuoles and forms very thick filaments whereas strain 6313 does not form gas vacuoles and has much thinner filaments. 
Table 5. Mean DNA base compositions of strains assigned to Section $V$

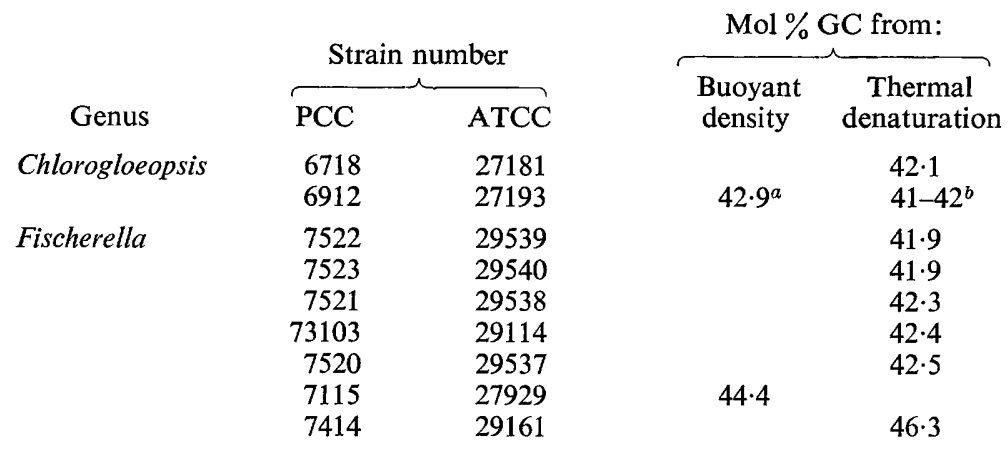

${ }^{a}$ From Stanier et al. (1971); ${ }^{b}$ from Craig et al. (1969).

The base compositional span of DNA for the 25 strains of the LPP group is wide: 42 to $67 \mathrm{~mol} \%$ GC (Table 3). Although the group is phenotypically diverse, there appears to be little correlation between phenotypic characters and DNA base composition. The bracketed cluster of five strains are the only representatives of the LPP group which appear closely similar to one another in phenotypic respects; they are also similar in base composition (46 to $50 \mathrm{~mol} \% \mathrm{GC}$ ). This strain cluster includes the organism that has been widely used for physiological studies (Stewart \& Lex, 1970; Padan et al., 1971) and as a host for LPP phages (Padan et al., 1970) under the name Plectonema boryanum.

Section IV comprises heterocystous cyanobacteria which form unbranched filaments. Only four base compositional values for cyanobacteria of this section have been previously published. The 35 strains included cover a considerable range of structural diversity; they include representatives both of the nostocacean (Anabaena, Nostoc, Cylindrospermum, Nodularia) and rivularian (Calothrix) types. The overall base compositional span is narrow: 38 to $47 \mathrm{~mol} \%$ GC (Table 4). For genera in which numerous strains have been analysed (e.g. Nostoc and Calothrix), the intrageneric spans almost correspond to that for Section IV in its entirety.

The strains assigned to Section $\mathrm{V}$ are the heterocystous cyanobacteria which form true branches (genus Fischerella) and Chlorogloeopsis, a virtually unicellular heterocyst-former which, like the true branchers, divides in more than one plane. The base compositional range for the nine strains analysed is narrow (42 to $46 \mathrm{~mol} \% \mathrm{GC}$, Table 5) and not significantly different from that of the heterocyst-formers of Section IV.

\section{DISCUSSION}

The wide span of mean DNA base composition among cyanobacteria - only slightly less than that for all prokaryotes - was established by Edelman et al. (1967) and Stanier et al. (1971). These workers analysed a relatively limited number of strains, heavily biased in favour of unicellular forms. The present study, conducted on a much larger and more representative strain collection, has revealed that major DNA base compositional divergences are confined to two cyanobacterial sub-groups: unicellular organisms that reproduce by binary fission ( 35 to $71 \mathrm{~mol} \% \mathrm{GC}$ ) and filamentous, non-heterocystous cyanobacteria ( 40 to $67 \mathrm{~mol} \% \mathrm{GC}$ ). For all other cyanobacteria, the overall range is only 38 to $47 \mathrm{~mol} \%$ GC. These include the heterocystous and the pleurocapsalean cyanobacteria, two subgroups which are large, internally diverse and very different with respect to structure and development. For both sub-groups, the DNA base compositional range is the same. This stands in striking contrast to the situation among unicellular cyanobacteria, where the range 


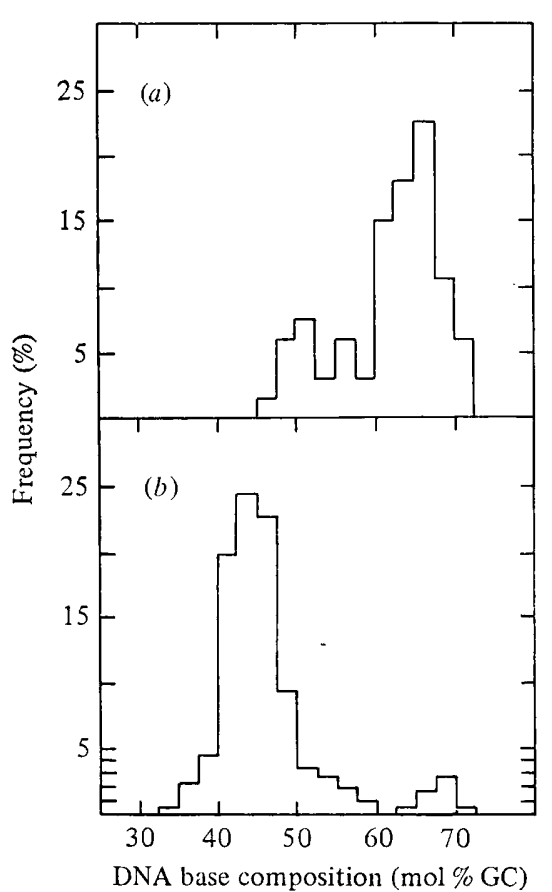

Fig. 1. Distribution of mean DNA base composition of $(a)$ photosynthetic bacteria (after Mandel et al., 1971) and (b) cyanobacteria.

for a single form genus, Synechococcus, extends from 39 to $71 \mathrm{~mol} \% \mathrm{GC}$. There is, accordingly, little or no correlation among cyanobacteria between divergences in mean DNA base composition on the one hand and diversity in structural and developmental respects on the other. This is paradoxical, since it is precisely in structural and developmental respects that the group appears most highly diverse; the gross metabolic properties of cyanobacteria are remarkably uniform (Stanier \& Cohen-Bazire, 1977).

Except possibly at the specific level, DNA base composition is not a useful taxonomic character among pleurocapsalean and heterocystous cyanobacteria. Among unicellular cyanobacteria, on the other hand, it emerges as a most important differential property. Both major form genera, Synechococcus and Synechocystis, can be sub-divided by virtue of significant base compositional discontinuities. The three ranges for Synechococcus are: 39 to 43,47 to 56 and 66 to $71 \mathrm{~mol} \%$ GC. The two ranges for Synechocystis are: 35 to 37 and 42 to $48 \mathrm{~mol} \%$ GC. In bacteriological taxonomic practice, discontinuities as marked as these could be used to justify generic separations.

Singer \& Ames (1970) hypothesized that the wide divergences of bacterial mean DNA base compositions, which range from 29 to $74 \mathrm{~mol} \% \mathrm{GC}$, are attributable at least in part to environmental selection by solar irradiance. They suggested that DNA with a high GC content might have been selected as a means of avoiding thymine-specific damage from ultraviolet irradiation; in support of this proposal, they showed that bacterial genera of high GC content are, in general, composed of organisms subject to solar irradiance in the natural habitat, whereas those of low GC content tend to be composed of organisms from habitats not subject to solar irradiance. Bak et al. (1972) listed a number of exceptions to this rule and concluded that (apart from counter-selection of extreme values) the distribution of bacterial GC contents is largely random. Obviously, all phototrophic prokaryotes are subject to solar irradiance; and, as predicted by Singer \& Ames (1970), nearly all purple and green bacteria possess DNAs which fall in the upper half of the GC scale. This is shown in 
Fig. 1(a), which summarizes the extensive data of Mandel et al. (1971). However, the cyanobacteria show a markedly different mean DNA base distribution (Fig. $1 b$ ), very few representatives possessing DNAs that fall into the upper range of the GC scale. The DNAs of the majority cluster slightly below the middle of the GC scale, and a few lie near its lower limit.

In many natural habitats, the intrinsic oxygen tolerance of cyanobacteria permits them to develop in direct contact with the atmosphere. This makes them considerably more liable to ultraviolet exposure than the purple and green bacteria, which develop in oxygen-free aqueous habitats, where they are covered by an ultraviolet-absorbing water overlayer. The DNA base compositional range of cyanobacteria therefore appears to be incompatible with the Singer-Ames hypothesis. We conclude that the nature of the selective pressures which have led to prokaryotic DNA base composition divergence remain largely unexplained.

The authors wish to thank Mme Josette Deruelles for her valuable help in providing the cell material. During the course of this work M.H. was the recipient of a European Science Exchange Programme Fellowship from The Royal Society. The research was in part supported by the Centre National de la Recherche Scientifique (E.R.A. 398).

\section{REFERENCES}

Bak, A. L., Atkins, J. F. \& MeYer, S. A. (1972). Evolution of DNA base compositions in microorganisms. Science 175, 1391-1393.

Bourrelly, P. (1970). Les Algues d'Eau Douce. Tome III: Les Algues Bleues et Rouges. Paris: N. Boubée.

Britten, R. J., Pavich, M. \& Smith, J. (1968). A new method for DNA purification. Yearbook of the Carnegie Institution of Washington 68, 400402.

Craig, I. W., Leach, C. K. \& Carr, N. G. (1969.) Studies with deoxyribonucleic acid from bluegreen algae. Archiv für Mikrobiologie 65, 218-227.

Edelman, M., Swinton, D., Schiff, J. A., EPstein, H. T. \& Zelden, B. (1967). Deoxyribonucleic acid of the blue-green algae (cyanophyta). Bacteriological Reviews 31, 315-331.

Kaye, A. M., Salomon, R. \& Fridlender, B. (1967). Base composition and presence of methylated bases in DNA from a blue-green alga Plectonema boryanum. Journal of Molecular Biology 24, 479-483.

Mandel, M., Leadbetter, E. R., Pfennig, N. \& TRÜPER, H. G. (1971). Deoxyribonucleic acid base compositions of phototrophic bacteria. International Journal of Systematic Bacteriology 21, 222-230.

MARMUR, J. \& DotY, P. (1962). Determination of the base composition of deoxyribonucleic acid from its thermal denaturation temperature. Journal of Molecular Biology 5, 109-118.

Padan, E., Ginzburg, D. \& Shilo, M. (1970). The reproductive cycle of cyanophage LPP-1 in Plectonema boryanum and its dependence on photosynthetic and respiratory systems. Virology 40, 514-521.

Padan, E., Raboy, B. \& Shilo, M. (1971). Endogenous dark respiration of the blue-green alga,
Plectonema boryanum. Journal of Bacteriology 106, 45-50.

RippKa, R., Waterbury, J. B. \& Cohen-Bazire, G. (1974). A cyanobacterium which lacks thylakoids. Archives of Microbiology 100, 419-436.

RipPKa, R., Deruelles, J., Waterbury, J. B., Herdman, M. \& Stanier, R. Y. (1979). Generic assignments, strain histories and properties of pure cultures of cyanobacteria. Journal of General Microbiology 111, 1-61.

SCHNEIDER, W. C. (1957). Determination of nucleic acids in tissues by pentose analysis. Methods in Enzymology 3, 680-684.

Singer, C. E. \& AMES, B. M. (1970). Sunlight ultraviolet and bacterial DNA base ratios. Science 170, 822-826.

STANier, R. Y. \& Cohen-Bazire, G. (1977). Photosynthetic prokaryotes: the cyanobacteria. Annual Review of Microbiology 31, 225-275.

Stanier, R. Y., Kunisawa, R., Mandel, M. \& Cohen-Bazire, G. (1971). Purification and properties of unicellular blue-green algae (Order Chroococcales). Bacteriological Reviews 35, 171205.

Stewart, W. D. P. \& LeX, M. (1970). Nitrogenase activity in the blue-green alga Plectonema boryanum strain 594. Archiv für Mikrobiologie 73, 250-260.

TAGgart, J. (1967). Heptulose phosphate synthesis and the transaldolase reaction in plant tissues. Ph.D. thesis, University of Liverpool.

Waterbury, J. B. \& Stanier, R. Y. (1977). Two unicellular cyanobacteria which reproduce by budding. Archives of Microbiology 115, 249-257.

Waterbury, J. B. \& STANIER, R. Y. (1978). Patterns of growth and development in pleurocapsalean cyanobacteria. Bacteriological Reviews 42, 2-44. 